\section{White Delight Peach Series, Four Medium-chill Subacid White-fleshed Peaches}

\author{
David H. Byrne ${ }^{1}$ and Natalie Anderson \\ Department of Horticultural Sciences, Texas A\&M University, Horticulture- \\ Forestry Science Building, College Station, TX 77843-2133
}

Additional index words. fruit breeding, low chilling, Prunus persica

The White Delight peach series is being released by Texas A\&M University. These four new peach cultivars would supply highquality, firm, attractive, subacid white-fleshed peaches over 6 weeks from late May until early July in the medium chill zone of Texas and similar areas.

\section{Origin}

The White Delight peach [Prunus persica (Batsch) L.] series originated in the Stone Fruit Breeding Program of the Department of Horticultural Sciences at Texas A\&M University, located in College Station, TX, from crosses between selections adapted to the low to medium chill zones (TX4D46W, TX2492-1, and TXW1591-1) and various subacid peaches from California ('Summer Sweet'), Japan ('Chiyohime'), and China ('Zao Hong Zhu'). 'White Delight One' (WD1), tested as TX4C236LW, is a cross between a yellow-fleshed, medium-chill peach selection (TX2492-1 = nectarine seedling $\times$ 'Earligrande') and the Japanese cultivar Chiyohime, which is an early-ripening subacid white-fleshed peach. 'Chiyohime' was released by the National Institute of Fruit Science (Tsukuba, Japan) in 1986 and is a hybrid between 'Koyohakuto' and 'Saotome' (Yoshida et al., 1987). 'White Delight Two' (WD2), tested as TX3E213LW, is a cross between the white-fleshed seedling selection TX4D46W and 'Summer Sweet', a patented peach released by Zaiger Genetics (Zaiger et al., 1992). TX4D46W was a whitefleshed peach selection from a seedling population derived from a cross between 'TexRoyal' and a subacid, white peach seedling. The parents of 'TexRoyal' (Byrne and Bacon, 1991) are NJ239 and 'Early Amber'. NJ 239 was derived from an open-pollinated seedling of the selection B1-75 whose parents are 'Fireglobe' and a seedling from 'Rio Oso Gem' and 'Sunbeam'. 'White Delight Three' (WD3), tested as TX4F223LW, and 'White Delight Four' (WD4), tested as TX4F194LW, are siblings from the cross between a low-chill, yellow-fleshed peach selection, TXW1591-1, and a subacid, white nectarine developed in

Received for publication 15 Mar. 2013. Accepted for publication 16 May 2013.

${ }^{1}$ To whom reprint requests should be addressed; e-mail dbyrne@tamu.edu. sites. Sharpe, 1970; Weinberger, 1956). from 1975 to 1996. units as estimated with the mean monthly temperature of the coldest month (Byrne and Bacon, 1992; Sharpe, 1970; Weinberger, 1956). Fairfield, TX (lat. $31^{\circ} 44^{\prime} \mathrm{N}$, long. $96^{\circ} 10^{\prime} \mathrm{W}, 134 \mathrm{~m}$ elevation) has a mean monthly temperature of it coldest month of $8.9{ }^{\circ} \mathrm{C}$ and a chilling accumulation that is generally greater than 750 chilling units. The Fowler, CA, site (lat. $36^{\circ} 38^{\prime} \mathrm{N}$, long. $119^{\circ} 42^{\prime} \mathrm{W}, 92 \mathrm{~m}$ elevation) has a mean monthly temperature of its coldest month of $7.9^{\circ} \mathrm{C}$ and has a chilling accumulation that is generally above 800 chilling units (Table 1 ).

\section{Description}

China, 'Zao Hong Zhu'. TXW1591-1 is a yellow-fleshed, acid peach derived from a cross between 'Tropicsweet' and the Florida selection FLA9-6N (Fla6-8 open-pollinated). 'Zao Hong Zhu' was released in 1994 by the breeding program of the Beijing Academy of Agriculture and Forest Science, Plant Protection and Environment Institute and was created by crossing the subacid, whitefleshed 'Jingyu' (= 'Okubo' $\times$ 'Okitsu') and the Arkansas selection A369 (=7761 openpollinated) (Lirong Wang, personal communication). A369 is a large late-ripening nectarine selected in Arkansas in 1986 and derived from materials developed in the New Jersey Fruit Breeding Program directed by Drs. Fred Hough and Catherine Bailey (John Clark, personal communication; Joseph Goffreda, personal communication). Resulting seed from these crosses were planted in 1998 and 1999 in a high-density breeding orchard at the Texas A\&M University Horticultural Farm in College Station, TX. During 2001 through 2003, these selections were marked for subsequent observation and noted as having exceptional characteristics.

Two-year-old and older trees of the selection were subsequently evaluated during the 2006 through 2011 fruit growing seasons in three locations: one medium-chill site (Fairfield, TX) and a higher chill location (Fowler, CA). WD2 was also tested in a low medium chill site at Floresville, TX (lat. $29^{\circ} 11^{\prime} \mathrm{N}$, long. $98^{\circ} 5^{\prime} \mathrm{W}, 155 \mathrm{~m}$ elevation), southeast of San Antonio, TX. The mean monthly temperature of its coldest month averages $\approx 11.5{ }^{\circ} \mathrm{C}$ and has a chilling accumulation that is generally above 450 chill

The White Delight peach series consists of four cultivars that are productive in the medium chill zones where cultivars such as 'TexKing' (Byrne and Bacon, 2004), 'TexRoyal', 'June Gold' (Brooks, 1958), and 'Scarlet Pearl' (Okie, 1993) are adapted. These ripen consecutively from late May through mid-July. This is the first high-quality, subacid, white peach series released for the medium-chill region of the eastern United States.

All of the White Delight peaches described bear crops of white-fleshed, subacid peaches, which are firm, very attractive, and large for the season (Tables 2-4). The fruit is generally round with a slight suture and/or tip protrusion, especially under lower chill conditions. The fruit have a cream white ground color, $30 \%$ to $80 \%$ striped red to orange red over color, creamy white melting type flesh color, and are clingstone (WD1, WD3, WD4) to semi-freestone (WD2) (Fig. 1). The fruit flesh does not brown readily nor has it shown a tendency to develop split or shattered pits during the final stage of fruit swelling. Fruit quality is equal to or better than that of the other major medium-chill commercial cultivars in terms of flesh firmness, shape, ground color, appearance, flavor, and total soluble solids (Tables 2-4).

In Floresville, the lowest chill site, only 'White Delight Two' was tested, showing consistent production. All four of the new cultivars produced consistently in the medium and high chill sites (Fairfield and Fowler). WD1 and WD2 bloom before the two later ripening cultivars, WD3 and WD4. Using the relative bloom times with standard

Table 1. Chilling conditions at two Texas (Floresville and Fairfield) and one California (Fowler) evaluation

\begin{tabular}{|c|c|c|c|c|c|c|c|}
\hline \multirow[b]{2}{*}{ Location } & \multicolumn{2}{|c|}{$\begin{array}{l}\text { December } \\
\text { temp }\left({ }^{\circ} \mathrm{C}\right)\end{array}$} & \multicolumn{2}{|c|}{$\begin{array}{l}\text { January } \\
\text { temp }\left({ }^{\circ} \mathrm{C}\right)\end{array}$} & \multicolumn{2}{|c|}{$\begin{array}{l}\text { Chilling } \\
\text { accumulation }^{\mathrm{z}}\end{array}$} & \multirow{2}{*}{$\begin{array}{c}\text { Common commercial } \\
\text { cultivars }\end{array}$} \\
\hline & Mean & Range & Mean & Range & Mean & Range & \\
\hline Floresville $^{\mathrm{y}}$ & 11.7 & $8.2-13.4$ & 11.5 & $9.1-14.6$ & 644 & $404-939$ & $\begin{array}{l}\text { TexKing, Flordaking, } \\
\text { TexPrince }\end{array}$ \\
\hline Fairfield & 9.4 & $6.8-10.8$ & 8.9 & $6.7-12.9$ & 947 & $757-1303$ & $\begin{array}{l}\text { June Gold, Harvester, } \\
\text { Julyprince, GaLa }\end{array}$ \\
\hline Fowler & 7.6 & $5.3-10.3$ & 7.9 & $5.1-12.0$ & 1119 & 788-1301 & O'Henry, Elegant Lady \\
\hline
\end{tabular}

${ }^{\mathrm{z}}$ Chilling estimated with the mean monthly temperatures of the two coldest months using the equation Chilling $=2079-\left(123.8 *\right.$ December/January mean monthly temperature in $\left.{ }^{\circ} \mathrm{C}\right)($ Byrne and Bacon, 1992;

${ }^{\mathrm{y}}$ Floresville used data from San Antonio, Fairfield used data from the Waco, and the Fowler used data from the Fresno weather station. All Texas sites used data from 2000 to 2011 and the California site used data 
Table 2. Fruiting characteristics of 'White Delight 2' compared with three medium chill peach cultivars at Floresville, TX (2005-10).

\begin{tabular}{|c|c|c|c|c|c|c|c|c|c|c|c|c|c|}
\hline Name & Full bloom ${ }^{z}$ & $\begin{array}{c}\text { FDP } \\
(\text { days })^{z}\end{array}$ & Ripe date ${ }^{z}$ & $\operatorname{Size}^{y}$ & $\begin{array}{l}\mathrm{Wt} \\
(\mathrm{g})\end{array}$ & Firm $^{x}$ & Blush $^{x}$ & Shape $^{x}$ & $\operatorname{Tip}^{x}$ & $\begin{array}{l}\text { Ground } \\
\text { color }^{\mathrm{x}}\end{array}$ & Appearance ${ }^{\mathrm{x}}$ & $\begin{array}{c}\text { Soluble } \\
\text { solids (Brix) }\end{array}$ & Taste $^{\mathrm{x}}$ \\
\hline Texking & 18 Feb. b & $89 \mathrm{ab}$ & 17 May b & 6.3 & $143 \mathrm{ab}$ & $6.9 \mathrm{~b}$ & $6.0 \mathrm{a}$ & $6.0 \mathrm{~b}$ & $6.3 \mathrm{a}$ & 6.9 & $6.9 \mathrm{a}$ & $9.9 \mathrm{bc}$ & $6.0 \mathrm{bc}$ \\
\hline White Delight 2 & 29 Feb. a & $91 \mathrm{a}$ & 05 June a & 6.0 & $127 \mathrm{~b}$ & $7.5 \mathrm{a}$ & $6.9 \mathrm{a}$ & $6.8 \mathrm{a}$ & $7.0 \mathrm{a}$ & 6.5 & $7.2 \mathrm{a}$ & $13.2 \mathrm{a}$ & $7.4 \mathrm{a}$ \\
\hline
\end{tabular}

${ }^{\mathrm{z}}$ Full bloom $=60 \%$ to $80 \%$ flowers open; FDP $=$ fruit development period, days from full bloom to ripe; Ripe date $=$ date when $20 \%$ of the fruit is firm ripe.

${ }^{\mathrm{y}}$ Size ratings of diameter (mm) 0 to $9 ; 4=51$ to $57,5=58$ to $64,6=65$ to $70,7=71$ to 76 .

${ }^{\times}$Rating scale 0 to $9 ; 0$ to $4=$ unacceptable, $5=$ marginal, $6=\operatorname{good}, 7=$ very good, 8 to $9=$ excellent for commercial use.

"Mean separation within columns by Duncan's multiple range test at the $5 \%$ level. Items with the same letter are not significantly different. No letters within a column indicates no significant differences.

Table 3. Fruiting characteristics of 'White Delight' peach series compared with four medium chill peach cultivars at Fairfield, TX (2006-11).

\begin{tabular}{|c|c|c|c|c|c|c|c|c|c|c|c|c|c|}
\hline Name & Full bloom ${ }^{2}$ & $\begin{array}{c}\text { FDP } \\
(\text { days })^{z}\end{array}$ & Ripe date ${ }^{z}$ & $\operatorname{Size}^{\mathrm{y}}$ & $\begin{array}{l}\text { Wt } \\
(\mathrm{g})\end{array}$ & Firm $^{x}$ & Blush $^{\mathrm{x}}$ & Shape $^{\mathrm{x}}$ & $\operatorname{Tip}^{x}$ & $\begin{array}{l}\text { Ground } \\
\text { color }^{\mathrm{x}}\end{array}$ & Appearance ${ }^{\mathrm{x}}$ & $\begin{array}{c}\text { Soluble } \\
\text { solids (Brix) }\end{array}$ & Taste $^{\mathrm{x}}$ \\
\hline$\overline{\text { Regal }}$ & 13 Mar. $a b^{w}$ & $70 \mathrm{e}$ & 21 May d & $5.2 \mathrm{~b}$ & $105 \mathrm{~d}$ & $7.0 \mathrm{~b}$ & $7.2 \mathrm{ab}$ & $6.6 \mathrm{bc}$ & $6.4 \mathrm{~cd}$ & $7.0 \mathrm{a}$ & $7.0 \mathrm{bc}$ & $10.8 \mathrm{c}$ & $6.3 \mathrm{c}$ \\
\hline White Delight 1 & 05 Mar. e & $81 \mathrm{~d}$ & 25 May cd & $6.2 \mathrm{ab}$ & $138 \mathrm{ad}$ & $6.8 \mathrm{~b}$ & 5.2 be & $7.6 \mathrm{a}$ & $7.7 \mathrm{a}$ & $6.4 \mathrm{ab}$ & $7.2 \mathrm{ab}$ & $12.0 \mathrm{ac}$ & $6.6 \mathrm{bc}$ \\
\hline JuneGold & 09 Mar. be & $84 \mathrm{~d}$ & 01 June c & $6.0 \mathrm{ab}$ & $130 \mathrm{ad}$ & $6.0 \mathrm{c}$ & $4.2 \mathrm{ef}$ & $6.2 \mathrm{c}$ & $5.8 \mathrm{~d}$ & $7.0 \mathrm{a}$ & $6.0 \mathrm{c}$ & $11.2 \mathrm{ac}$ & $6.6 \mathrm{bc}$ \\
\hline TexRoyal & 08 Mar. be & $97 \mathrm{c}$ & 13 June $b$ & $5.8 \mathrm{ab}$ & $116 \mathrm{bd}$ & $7.0 \mathrm{ab}$ & $7.3 \mathrm{ab}$ & $7.1 \mathrm{ab}$ & $7.2 \mathrm{ab}$ & $6.5 \mathrm{ab}$ & $6.9 \mathrm{bc}$ & $11.0 \mathrm{bc}$ & $6.6 \mathrm{bc}$ \\
\hline Scarlet Pearl & 16 Mar. a & $98 \mathrm{c}$ & 15 June $b$ & $7.0 \mathrm{a}$ & $165 \mathrm{a}$ & $7.3 \mathrm{ab}$ & $6.0 \mathrm{ae}$ & $7.1 \mathrm{ab}$ & $7.1 \mathrm{ac}$ & $6.7 \mathrm{ab}$ & $6.8 \mathrm{bc}$ & $11.9 \mathrm{ac}$ & $6.4 \mathrm{bc}$ \\
\hline White Delight 2 & 06 Mar. e & $104 \mathrm{bc}$ & 18 June $b$ & $6.1 \mathrm{ab}$ & $141 \mathrm{ad}$ & $7.8 \mathrm{a}$ & $8.0 \mathrm{a}$ & $7.3 \mathrm{ab}$ & $7.6 \mathrm{ab}$ & $6.5 \mathrm{ab}$ & $8.1 \mathrm{a}$ & $13.5 \mathrm{ac}$ & $7.4 \mathrm{ab}$ \\
\hline White Delight 3 & 12 Mar. ac & $112 \mathrm{ab}$ & 29 June a & $5.8 \mathrm{ab}$ & $148 \mathrm{ac}$ & $7.1 \mathrm{ab}$ & $4.8 \mathrm{df}$ & $6.9 \mathrm{ac}$ & $6.8 \mathrm{bc}$ & $6.0 \mathrm{~b}$ & $6.0 \mathrm{c}$ & $14.3 \mathrm{a}$ & $7.5 \mathrm{a}$ \\
\hline White Delight 4 & 11 Mar. ad & $114 \mathrm{a}$ & 4 July a & $6.3 \mathrm{ab}$ & $144 \mathrm{ac}$ & $7.7 \mathrm{a}$ & $3.1 \mathrm{f}$ & $7.0 \mathrm{ab}$ & $7.1 \mathrm{ac}$ & $6.2 \mathrm{ab}$ & $6.3 \mathrm{bc}$ & $14.2 \mathrm{a}$ & $6.9 \mathrm{bc}$ \\
\hline
\end{tabular}

${ }^{\mathrm{z} F u l l}$ bloom $=60 \%$ to $80 \%$ flowers open; FDP $=$ fruit development period, days from full bloom to ripe; Ripe date $=$ date when $20 \%$ of the fruit is firm ripe.

${ }^{y}$ Size ratings of diameter ( $\left.\mathrm{mm}\right) 0$ to $9 ; 4=51$ to $57,5=58$ to $64,6=65$ to $70,7=71$ to 76 .

${ }^{x}$ Rating scale 0 to $9 ; 0$ to $4=$ unacceptable, $5=$ marginal, $6=$ good, $7=$ very good, 8 to $9=$ excellent for commercial use

${ }^{\text {w}}$ Mean separation within columns by Duncan's multiple range test at the $5 \%$ level. Items with the same letter are not significantly different. No letters within a column indicates no significant differences

Table 4. Fruiting characteristics of 'White Delight' peach series compared with three medium chill peach cultivars at Fowler, CA (2006-11).

\begin{tabular}{|c|c|c|c|c|c|c|c|c|c|c|c|c|c|}
\hline Name & Full bloom ${ }^{z}$ & 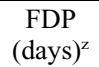 & Ripe date ${ }^{z}$ & $\operatorname{Size}^{y}$ & $\begin{array}{l}\mathrm{Wt} \\
(\mathrm{g})\end{array}$ & $\operatorname{Firm}^{\mathrm{x}}$ & Blush $^{\mathrm{x}}$ & Shape $^{\mathrm{x}}$ & $\operatorname{Tip}^{\mathrm{x}}$ & $\begin{array}{l}\text { Ground } \\
\text { color }^{\mathrm{x}}\end{array}$ & Appearance ${ }^{\mathrm{x}}$ & $\begin{array}{c}\text { Soluble } \\
\text { solids (Brix) }\end{array}$ & Taste $^{\mathrm{x}}$ \\
\hline Flordaking & 25 Feb. $\mathrm{c}^{\mathrm{w}}$ & $84 \mathrm{~d}$ & 22 May f & 7.0 & 177 & 6.5 & $3.0 \mathrm{c}$ & 7.2 & $7.2 \mathrm{~b}$ & $6.3 \mathrm{bc}$ & $5.4 \mathrm{~d}$ & 11.0 & 6.0 \\
\hline White Robin & 24 Feb. c & $90 \mathrm{~cd}$ & 05 June de & 7.3 & 172 & 6.3 & $6.0 \mathrm{ab}$ & 7.3 & $7.5 \mathrm{ab}$ & $6.7 \mathrm{ac}$ & $7.0 \mathrm{ac}$ & 11.7 & 6.5 \\
\hline TexKing & 27 Feb. bc & 98 bc & 06 June de & 7.2 & 192 & 6.9 & $6.6 \mathrm{a}$ & 7.3 & $7.4 \mathrm{ab}$ & $6.8 \mathrm{ac}$ & $7.0 \mathrm{ac}$ & 11.1 & 6.2 \\
\hline White Delight 1 & 25 Feb. c & $102 \mathrm{bc}$ & 06 June de & 7.6 & 193 & 6.2 & $6.6 \mathrm{a}$ & 7.7 & $7.4 \mathrm{ab}$ & $6.2 \mathrm{bc}$ & $6.9 \mathrm{bc}$ & 12.5 & 6.6 \\
\hline White Delight 2 & 25 Feb. c & $110 \mathrm{~b}$ & 16 June c & 8.0 & 228 & 7.4 & $7.0 \mathrm{a}$ & 7.7 & $7.7 \mathrm{ab}$ & $6.9 \mathrm{ac}$ & $8.1 \mathrm{a}$ & 12.8 & 6.7 \\
\hline White Delight 3 & 06 Mar. a & $127 \mathrm{a}$ & 04 July b & 7.3 & 240 & 7.4 & $5.2 \mathrm{ab}$ & 7.7 & $7.8 \mathrm{a}$ & $6.3 \mathrm{bc}$ & $6.8 \mathrm{ac}$ & 12.8 & 6.8 \\
\hline White Delight 4 & 04 Mar. ab & $131 \mathrm{a}$ & 12 July a & 7.8 & 234 & 6.7 & $5.8 \mathrm{ab}$ & 7.3 & $7.3 \mathrm{ab}$ & $7.3 \mathrm{a}$ & $7.5 \mathrm{ac}$ & 13.3 & 6.8 \\
\hline
\end{tabular}

${ }^{\mathrm{z}}$ Full bloom $=60 \%$ to $80 \%$ flowers open; FDP $=$ fruit development period, days from full bloom to ripe; Ripe date $=$ date when $20 \%$ of the fruit is firm ripe.

${ }^{y}$ Size ratings of diameter $(\mathrm{mm}) 0$ to $9 ; 4=51$ to $57,5=58$ to $64,6=65$ to $70,7=71$ to 76 .

${ }^{x}$ Rating scale 0 to $9 ; 0$ to $4=$ unacceptable, $5=$ marginal, $6=$ good, $7=$ very good, 8 to $9=$ excellent for commercial use.

${ }^{\text {w} M e a n ~ s e p a r a t i o n ~ w i t h i n ~ c o l u m n s ~ b y ~ D u n c a n ' s ~ m u l t i p l e ~ r a n g e ~ t e s t ~ a t ~ t h e ~} 5 \%$ level. Items with the same letter are not significantly different. No letters within

a column indicates no significant differences.

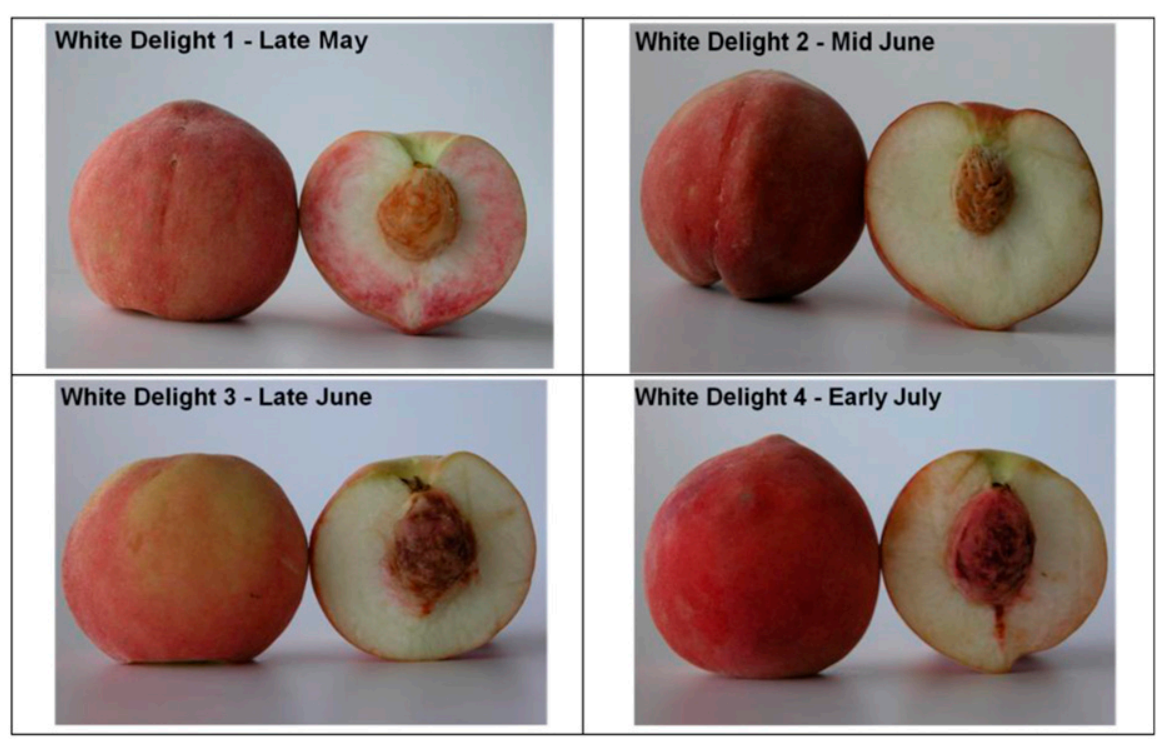

Fig. 1. Fruit of the White Delight subacid peach series. cultivars ['TexKing' (450 CR), 'Texstar' (550 CR), 'June Gold' (650 CR), 'Harvester' $(750 \mathrm{CR})]$ in the medium-chill zone in Texas (Floresville, College Station, Fairfield), the estimated chilling requirement for WD1 and WD2 is $\approx 550 \mathrm{~h}$ and for WD3 and WD4 is $\approx 700$ h of chilling temperatures (Tables 2-4).

The earliest of these, WD1, ripens in late May or early June and is followed in midJune by WD2. WD3 ripens in late June and early July and WD4 ripens in early to midJuly. Each new cultivar ripens 10 to $15 \mathrm{~d}$ after the previous one, which allows a continuous supply of high-quality fruit for 6 weeks (Tables 3 and 4).

The stones are elliptical to ovate in shape. WD1, WD3, and WD4 have larger stones (length 34 to $36 \mathrm{~mm}$, width 23 to $28 \mathrm{~mm}$, thickness 17 to $21 \mathrm{~mm}$ ) than those of WD2 (length 27 to $34 \mathrm{~mm}$, width 17 to $18 \mathrm{~mm}$, thickness 15 to $16 \mathrm{~mm}$ ). The dry stone surfaces of all cultivars are honeycombed with pit grooves. 
Flowers of WD1 and WD2 are non-showy, whereas WD3 and WD4 have showy flowers. All have five pink petals with the non-showy petals being a darker pink and smaller than the showy petals. Pollen is yellow and abundant. The tree is self-fertile.

The trees are vigorous with the typical semispreading growth habit similar to 'TexKing', 'TexPrince', and 'TexRoyal'. No observations have been made on resistance for either peach rust or bacterial leaf spot. The moderately large leaves are lanceolate with acuminate apices and crenate margins. WD1 and WD2 have zero to four small globular petiolar glands, whereas WD3 and WD4 have reniform petiolar glands.

\section{Availability}

Requests for propagation licenses should be directed to the Texas A\&M University System's Office of Technology Commercialization. These cultivars are the subject of plant patent applications.

\section{Literature Cited}

Brooks, R.M. 1958. Double Delight, Earligold, and June Gold peaches. Fruit Var. J. 3:22.

Byrne, D.H. and T.A. Bacon. 1991. 'TexRoyal', a medium chilling peach. HortScience 26:13381340.

Byrne, D.H. and T.A. Bacon. 1992. Chilling estimation: Its importance and estimation. The Texas Horticulturist 18:5, 8-9.
Byrne, D.H. and T.A. Bacon. 2004. 'TexKing', an early ripening medium chill peach. HortScience 39:442-443.

Okie, W.R. 1993. 'Goldprince' and 'Scarletpearl' peaches. HortScience 28:231.

Sharpe, R.H. 1970. Subtropical peaches and nectarines. Fla. State Hort. Soc. 82:302-306.

Weinberger, J.H. 1956. Prolonged dormancy trouble in peaches in the southeast in relation to winter temperatures. Proc. Amer. Soc. Hort. Sci. 67:107-112.

Yoshida, M., M. Yamaguchi, H. Kyotani, T. Kozono, T. Nishida, and Y. Ishizawa. 1987. New peach cultivar 'Chiyohime' Bull. Fruit Tree Res. Sta. Series A 14:1-8.

Zaiger, C.F., G.N. Zaiger, L.M. Gardner, and G.G. Zaiger. 1992. Peach tree "Summer Sweet." U.S. Plant Patent No. 8,070. 22 Dec. 1992. 